\title{
Increasing Student's Correspondence Course Study Result with Development of Adobe Flash Android-Based Media
}

\author{
Devi Artha Bonita \\ Sarbini \\ Program Studi Pendidikan Administrasi Perkantoran, Universitas Negeri Malang \\ Maimunah \\ SMK Muhammadiyah 5 Kepanjen \\ Email: sarbini.fe@um.ac.id
}

\begin{abstract}
The purpose of this study is to produce an Adobe Flash-based Android learning media on subjects that have tested the feasibility of the media through validation testing increased students result. This type of research is research and development ( $R \& D)$. This product is validated by material experts, media experts, and small groups and have been tasted in the experimental class. The results showed the development of Adobe Flash-based learning media Android is a significant improvement of students result.
\end{abstract}

Keyword: Learning Media, Adobe Flash, Android, Correspondence Subjects, Student's Result

Education able to change human mindset in order to facing problem (Schroder, et al., 2017; Schroder, et al., 2014; Orr \& Kukner, 2015). In Indonesia, education quality still low if we compared with other country. Based on Economic Co-Operation and Development (OECD) which publish World Education Ranking, Indonesia placed rank 57 from 65 countries (Kemendikbud, 2016). Based on that data, Indonesia need to do solving problem which related with education, especially to model and learning media.

2013 curriculum is government effort in order to overcome problem which related with education. Learning in 2013 curriculum context is learning with basis of attitude, skill, and knowledge (Amoros \& Solano, 2017; Yada, \& Savolainen, 2016; Siddiq \& Wilson, 2016). 2013 curriculum developed to improve and balance soft skills ability and hard skills such as attitude, skill, and knowledge. Approach which used is scientific approach which is involve observing, questioning, experiment, associating, and communicating (Dragons \& Mih, 2015 Vondel, et al., 2017). Hopefully, with 2013 curriculum able to prepare human resource which faithful, productive, creative, innovative, effective, and able to contribute to society, country, and world (Permendikbud, 2013).

One of the determinant of objective achievement from 2013 curriculum is learning successful. Whereas learning success depend on model and media which have interactive interface (Paola, Pedone \& Pizzurro, 2013; Gillham, et al., 2015; Caresia, 2017; Hsiao \& Chen, 2016). A teacher needs media to make material presenting while learning easier. Media which used by a teacher need to innovative and following technology development. 
Comparison of learning with 2013 curriculum and KTSP is constructive learning objective, from teacher centered become student centered. Hopefully, those changing make students able to exploring, processing, and finding knowledge by their own, whil teacher only as facilitator (Clarke, 2010; Wang, 2011; Roman, 2015; Tyabaev, Sedelnikova \& Voytivich, 2015). Hopefully, teacher can provide facility which able to make happy learning process with students. One of those is providing media which fit and attract students in order to achieve learning objective.

Learning media is teacher media in order to present study material to students is idea, think, and opinion (Carmona \& Chacon, 2017; Karadeniz \& Can, 2015; Karaduman, 2015; Sisman \& Yurttas, 2015; Ceretti, 2015; Alvarez, et al., 2013; Lee, et al., 2015; Karaduman, 2013). Using learning media make student have will and passion to learn study material. One objective of use learning media is attracting student's passion to learn material in class. While choosing media also need to attention to class characteristics, learning objective, and material which will be delivered.

Learning media have benefit toward learning process. One of those benefits is able to attract student's passion and makes learning interactive. Using correct learning media will make students accept study material easier. Besides that, correct learning media can be influencing students study result (Diergarten, et al., 2017; Nookhoong \& Wannapiroon, 2015; Norman. \& Furnes, 2016; Alabdulkareem, 2015).

Based on explanation above, researcher tend to develop correspondence learning media with Adobe Flash Android-based application. This Adobe Flash Android-based media is media which make teacher easier in order to explaining material and able to use by students to learn material individually.

Objective of this research are 1) making Correspondence learning media with Adobe Flash Android-based application in basic competence how to make formal letter; 2) finds feasibility of correspondence learning media which developed through validation result from experts and students as user; 3) finds differences between study result of students use media and students don't use media.

\section{METHOD}

Learning media product development design using research and development step which stated by Borg and Gall (1983) in Setyosari (2013: 292-294). Those research and development steps include: (1) Research and collecting initial information, (2) Planning, (3) Development of initial product, (4) Initial trial, (5) Product revision, (6) In-field trial, (7) Product revision, (8) In-field trial, (9) Final product revision, (10) Dissemination and implementation.

Based on research and development steps which developed by Borg and Gall in Setyosari (2013: 295-294), number of trial subject in experiment class is 37 students and control class is 32 students. Media validation involving two experts, which is study material expert from teacher which understand correspondence material in SMK Muhammadiyah 5 Kepanjen, and media expert from TEP lecture Faculty of Education in Universitas Negeri Malang. Needs data analysis analyzed qualitatively and quantitatively. Expert review data about development of correspondence media using Adobe Flash Android-based is score change to 
qualitative data (interval data) with four scale. Student study result analysis did with post-test.

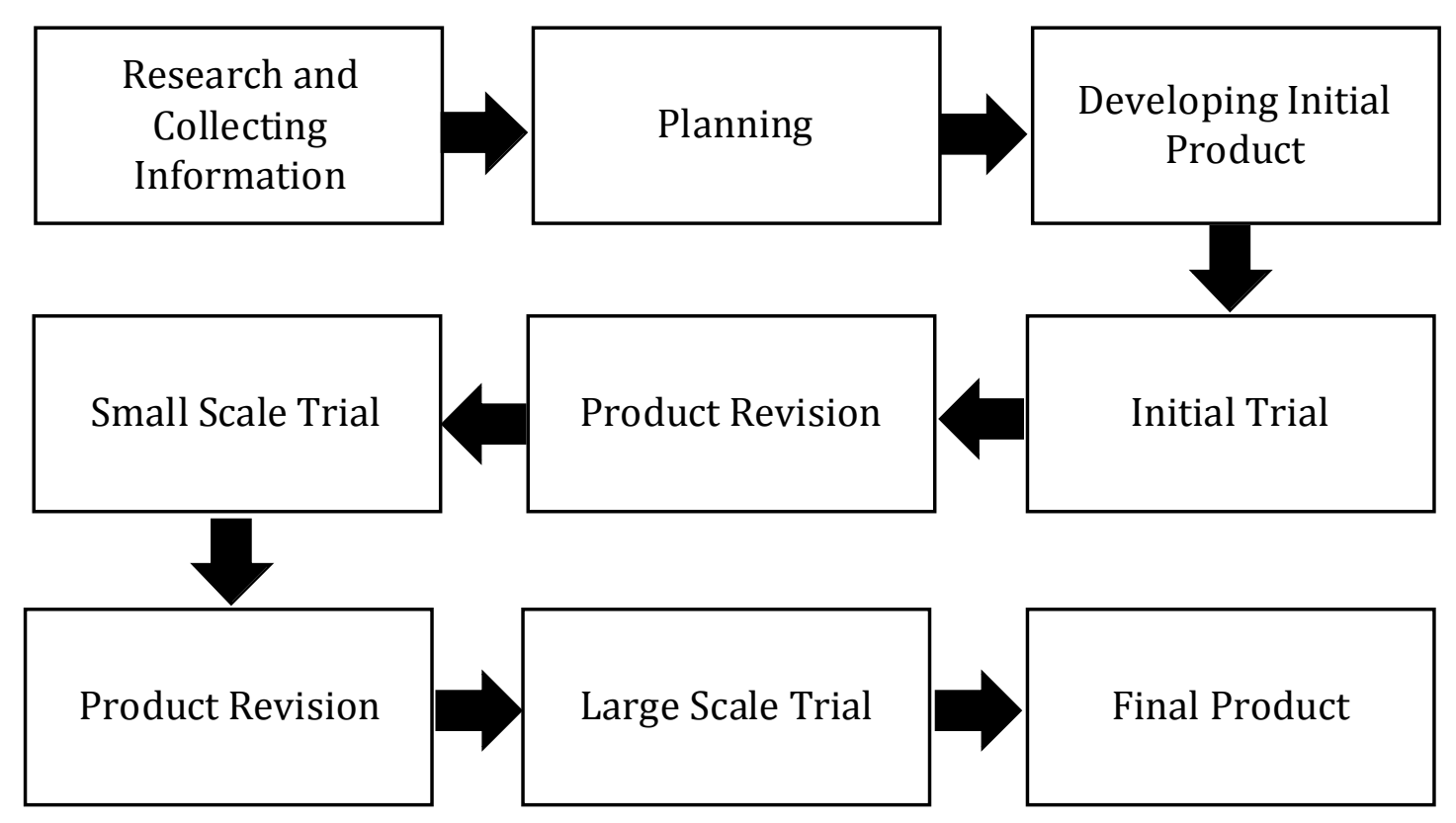

Figure 1 Modified Research and Development Procedure by Borg \& Gall student are:

Validation result which gave into study material expert, media expert, and

Table 1. Assessment Result from Study Material Expert

\begin{tabular}{clcccc}
\hline \multicolumn{7}{c}{ STUDY MATERIAL EXPERT } \\
\hline Validator & Aspect & $\mathbf{X}$ & $\mathbf{2 x i}$ & $\mathbf{\%}$ & Criteria \\
\hline Study Material & Learning & 19 & 24 & 79 & Very Valid \\
\cline { 2 - 6 } Expert & Material & 26 & 32 & 81,3 & Very Valid \\
\hline \multicolumn{7}{c}{ Average } \\
\hline
\end{tabular}

Validation result from study material expert shows that learning media Adobe Flash Android-based have been valid and feasible to tested in experiment class, we can see at Table 1.

Table 2. Assessment Result from Media Expert

\begin{tabular}{cllccc}
\hline \multicolumn{5}{c}{ MEDIA EXPERT } \\
\hline \multirow{4}{*}{ Validator } & \multicolumn{1}{c}{ Variable } & $\mathbf{E x}$ & $\mathbf{\Sigma x i}$ & $\mathbf{\%}$ & Criteria \\
\hline \multirow{3}{*}{ Media Expert } & Navigation & 10 & 12 & 83 & Very Valid \\
\cline { 2 - 6 } & Easiness to use & 11 & 12 & 92 & Very Valid \\
\cline { 2 - 6 } & Text & 12 & 12 & 100 & Very Valid \\
\cline { 2 - 6 } & Interface & 20 & 20 & 100 & Very Valid \\
\hline & Average & & & 93,75 & Very Valid \\
\hline
\end{tabular}

Validation result from media expert shows that learning media Adobe Flash Android-based have been valid and feasible to tested in experiment class. 
Table 3. Assessment Result from Students

\begin{tabular}{clllll}
\hline \multicolumn{7}{c}{ STUDENTS } \\
\hline Validator & \multicolumn{1}{c}{ Variable } & $\mathbf{2 x}$ & $\mathbf{2 x i}$ & $\mathbf{\%}$ & Criteria \\
\hline \multirow{2}{*}{ Small Group } & Easiness to use & 10,8 & 12 & 90 & Very Valid \\
\cline { 2 - 7 } Students & Attractiveness & 22,7 & 24 & 95 & Very Valid \\
\cline { 2 - 7 } & Material Presentation & 10,7 & 12 & 90 & Very Valid \\
\hline \multicolumn{2}{c}{ Average } & & 92 & Very Valid \\
\hline
\end{tabular}

Assessment result from small size students shows that learning media Adobe Flash Android-based have been valid and feasible to tested in experiment class. There is guideline in order to determine media feasible which have been develop:

Table 4. Media Feasibility Criteria

\begin{tabular}{ccc}
\hline Percentage & Criteria & Notes \\
\hline $84 \%-100 \%$ & Very valid & Very feasible, no revision needed \\
\hline $68 \%-84 \%$ & Valid & Feasible, no revision needed \\
\hline $52 \%-68 \%$ & Valid enough & Feasible enough, revision needed \\
\hline $20 \%-36 \%$ & Invalid & Not feasible, total revision needed \\
\hline (Source: Arikunto, 2001:245) & &
\end{tabular}

\section{RESULT \& DISCUSSIONS}

\section{Result}

This media development focused to basic competence of How to Make Formal Letter. Development of Adobe Flash Android-based learning media developed by using Adobe Flash as main software and Corel Draw X5 as supporting software. This application able to run in Android mobile phone which have Adobe Air. Programming language which used is ActionScript.

Product which developed by researcher is Adobe Flash Android-based applications. This application is "Beres" (Belajar Korespondensi) application. There are three components which developed in this research, which is introduction, main material, and closing which will explained below.

A. Introduction section

1. Initial interface

Initial interface in Adobe Flash Android-based learning media is "Beres" application's symbol and for go to next menu, it has to clicked first.

2. Main menu interface

Main menu interface which in Adobe Flash Android-based learning media which developed by researcher consist of three menus, which are KI/KD menu, Letter Material, and Try Out Question.

B. Main Sections

Main part is explanation of KI/KD, Letter Material and Exercise. KI/KD (Kompetensi Inti/Kompetensi Dasar), is part which shows competency which will achieve when 
learning. Besides, there is indicator of competency achievement which have to achieved by students.

Formal Letter Material, is sections which contains materials of Basic Competency 3.3 and 4.3. Besides material, there is example of formal letter so students have real vision about formal letter material. Hopefully, students attract to learn formal letter material. Those materials about kind of formal letter had been grouped in every menu, so students easier to understand those materials.

Try out questions, is section which contains exercise for students in order to train cognitive capability and their psychomotor for formal letter material. Exercise given in 2 kinds, are multiple choice exercise and analytic exercise. In multiple choice exercise, there is interface which shows student's score after do those questions. While in analytic exercise, there is exercise questions in case questions, from those case students make letters which fit with given directions and instructions.

\section{Closing Section}

Closing section contains creator profile and exit button. Creator profile, is section which shows profile of researcher which developing Adobe Flash Android-based learning media of Correspondence course for formal letter material. Ending interface in Adobe Flash Android-based is exit button which able to use if user want to exit from "Beres" application.

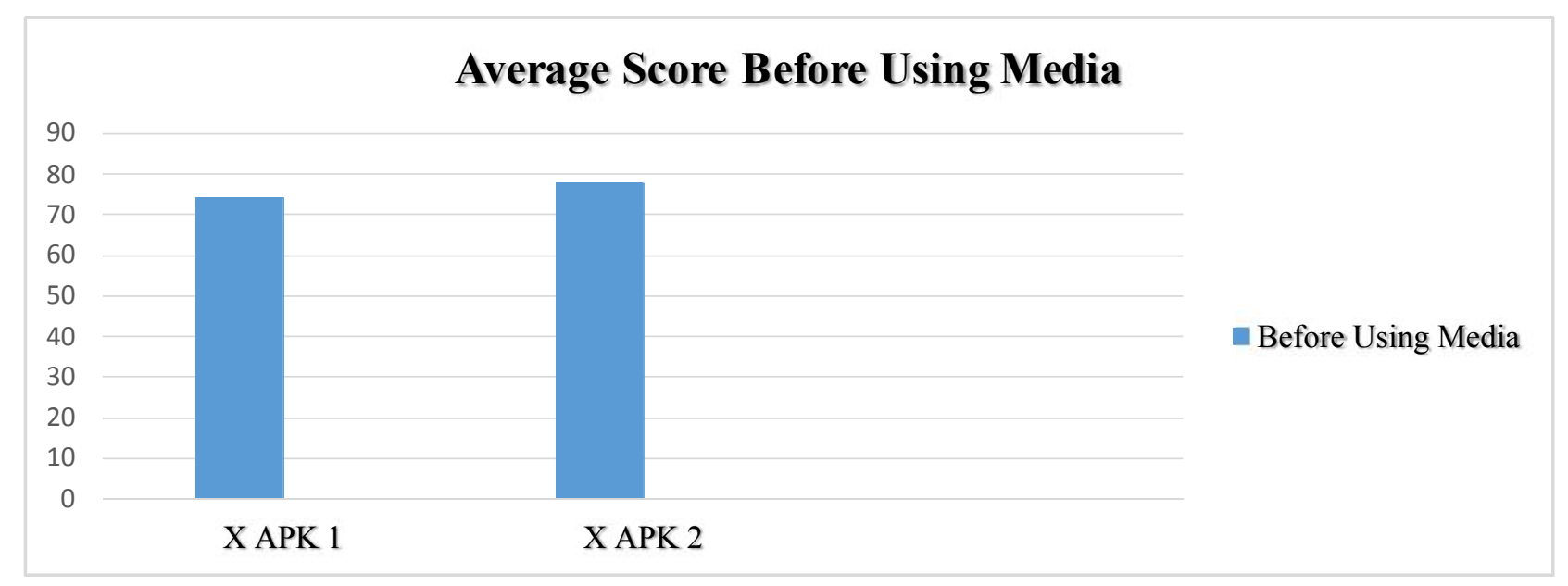

Figure 2. Average Score Before Using Media

Post-test done to know difference between student's study result when before using media and after using Adobe Flash Android-based "Beres" application media. Below is average student score after using media. 


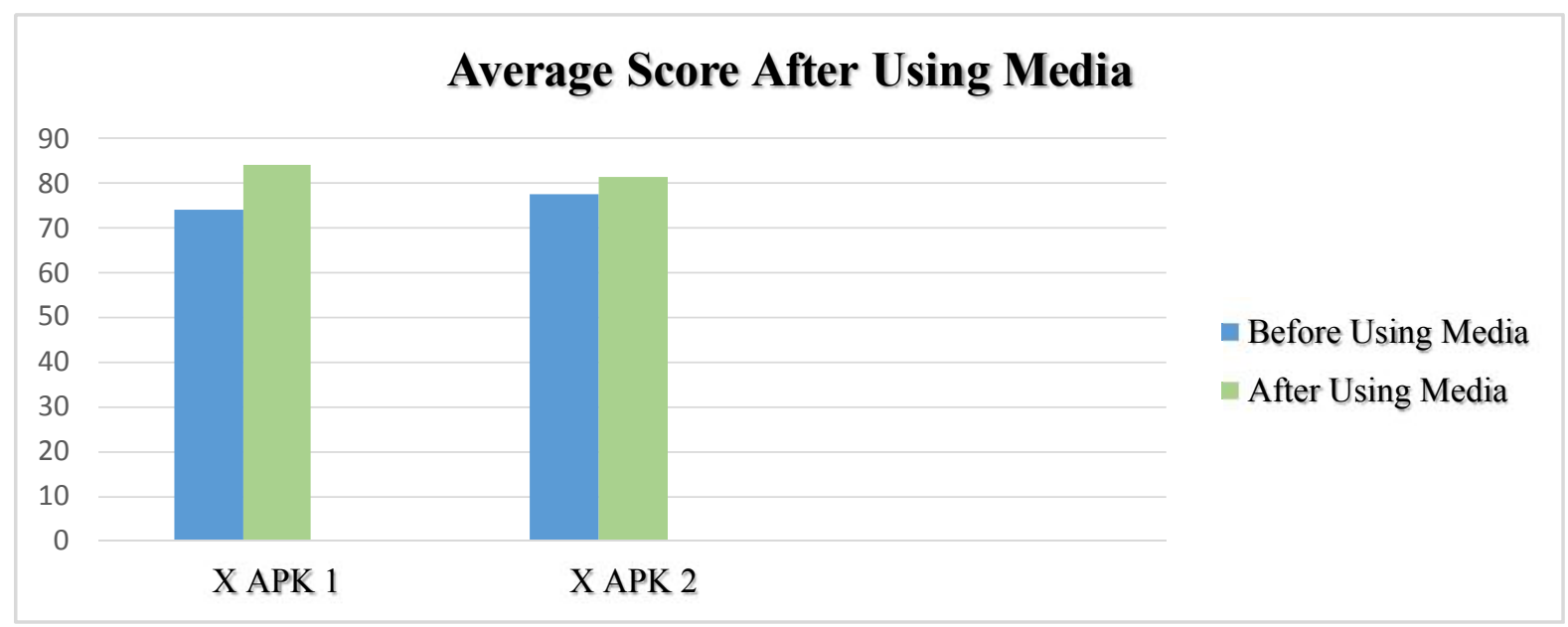

Figure 3. Average Score After Using Media

After did post-test, then doing calculation of completeness level of Basic Competence which have taught, with KKM score is 75. Below is analysis of student learning in control class and experiment class.

Table 5. Students Study Result

\begin{tabular}{lcc}
\hline & Control & Experiment \\
\hline Number of students & 32 & 37 \\
\hline Total score of all students & 2608 & 3108 \\
\hline Average score in class & 81,5 & 84 \\
\hline $\begin{array}{l}\text { Number of student which } \\
\text { complete }\end{array}$ & 30 & 37 \\
\hline $\begin{array}{l}\text { \% Number of student which } \\
\text { complete }\end{array}$ & $93,75 \%$ & $100 \%$ \\
\hline
\end{tabular}

Based on table 5 able to know that average value of student study result which using learning media Adobe Flash Android-based is higher than class which didn't use learning media in learning activity. Student score average differences between experiment class and control is 2.5. By those result, can conclude that Adobe Flash Android-based learning media can increasing student's study result.

\section{Discussions}

Development research which done by researcher is producing learning media, which is Correspondence learning media with Adobe Flash Android-based application in basic competence of Explaining How to Make Formal Letter. This learning media special designed for supporting learning in class for XI grade students with Office Administration concentration in SMK Muhammadiyah 5 Kepanjen based on Curriculum 2013. 
Learning media development Adobe Flash Android-based is one of interactive learning media which able to make student learning material easier. Based on Mahajan (2012:5) said that multimedia which following technology able to create interactive learning for students. Besides, based on Waseem (2016:1), learning media able to create better and innovative understanding. Learning media which developed designed with picture, animation, and writing also example of formal letter so students easier to learn formal letter material. Media which developed by researcher is visual media which completed with animation and pictures which support learning material. Based on Kusumajaya (2016:94), visual media able to attract attention and student's will. While choosing this learning media, research using ASSURE steps, are 1) Analyze learners, 2) State objectives, 3) Select media and materials, 4) Utilize materials, 5) Require learner's performance, and 6) Evaluate/revise. Attention to media choosing method able to produce learning media which fit with condition and characteristic from students.

Advantages of this media is student easier to understand a study material. Based on Taheri et al. (2016:31) that students with learning media's help able to understand material concept better. Learning media Adobe Flash Android-based contain learning material which able to learn by students individually and critical thinking. Based on Friedman (2016:31), learning media have to make student study individually, attention for surrounding, and critical for solving problem.

Other advantages of learning media which developed by researcher is students able to study whenever and wherever with open formal letter material through Android mobile phone which student have. Based on Shadarma, et al. (2011:1), learning media need to stand-alone and able to accessed every time. In learning media Adobe Flash Android-based, there are multiple choice exercise and analytical questions, so student able to train their ability. This thing is supporting with research which done by Olabiyi (2013:80) which said that learning media and technology able to use in order to development of students skill. In "Beres" application, there are example of formal letter which is for everyday use. Giving those examples of formal letter fit with learning cone by Edgar Dale (Sanjaya, 2008:200) is more concrete students learning a material, more experiences which will students get, otherwise more abstract student get experience, less experience which will student get. With giving examples of formal letter making students which only imagine, now able to look object reality about formal letter materials.

Weakness of this media is in order to use learning media Adobe Flash Android-based need supporting facilities, which is Android mobile phone, so this media didn't able to implement in every school, only certain school which all of students has Android mobile phone. In line with research which done by Agbo (2015:71) said that efficient and uses of effective technology depend on availability of hardware and software also spreading of teacher, students, and administrative staff access. Because of that, facility also supporting successful of media uses when learning in class.

Feasibility test result of learning media Adobe Flash Android-based for Correspondence course shows that media which developed by researcher very valid/very feasible to use as teaching media which able to support learning activity in class. Based on media validation result which done by study material expert got validation percentage $80 \%$, media expert validation percentage $95 \%$, and small size 
group validation percentage $91 \%$. Questionnaire which given to experiment class to know student's assessment toward learning media Adobe Flash Android-based as user of Beres (Belajar Korespondensi) application. Result of those questionnaires got percentage $84 \%$ which able to conclude that those media is valid and feasible to used. Based on validation score which presented, so learning media which developed by researcher stated very valid or very feasible to use as alternative learning media. In line with Fajriah \& Churiah (2013:100) research, learning media which is effective if there are improving of study result after using those learning media.

Post-test result shows that there are differences between student study result in experiment class before and after using media. Average students study result before using media in experiment class is 74, after using media Adobe Flash Android-based average student study result increase to 83.1, while average student study result in control class before using media is 77.5, student study result after using media is 79.2. Increasing in experiment class is bigger than control class. Completeness of student study result in experiment class is $100 \%$, while in control class is 93.75\%. Based on Jaradat (2013:127), there are correlations between technology and student's motivations". Besides, based on Putri et al. (2016:133) said that visual learning media able to increase student study result. Based on those comparison of those value, it can conclude that learning using learning media Adobe Flash Android-based able to increase student study result Correspondence course in SMK Muhammadiyah 5 Kepanjen. Those research result is supporting with theory which revealed by Hosnan (2014:129), that media have function to attract student's attention, student passion, and make student easier to study and easier to teach for teacher.

\section{CONCLUSIONS \& SUGGESTIONS}

\section{Conclusions}

Conclusions of this research and development are 1) making product Correspondence learning media with Adobe Flash Android-based into basic competence Explaining How to Make Formal Letter for SMK/MAK class X student with Office Administration concentration, 2)Learning media Adobe Flash Androidbased into Correspondence course based on validation test is feasible to used, and 3) result of student study based on post-test, class which use media have higher average result than class which don't use media.

\section{Suggestions}

Based on conclusion above, researcher suggest (1) for learning media Adobe Flash Android-based user previously need to install software AdobeAir which functioning as supporting learning media Adobe Flash Android-based software, (2) make sure that application completely installed in Android mobile phone device. (3) for teacher need to supervise student when using learning media Adobe Flash Android-based so learning process well done. Beside that, this development product able to publish through MGMP so product give positive impact for learning sustainability. 


\section{REFERENCE LIST}

Agbo, I., S. 2015. Factors Influencing The Use of Information and Communication Technology (ICT) in Teaching and Learning Computer Studies in Ohaukwu Local Government Area of Ebonyi State-Nigeria. Journal of Education and Practice. (Online), 6 (7): 71-85, (www.iiste.org), diakses 2 Maret 2017

Alvarez, C. Salavati, S. Nussubaum, M. \& Milrad, M. 2013. Callboard: Fostering New Media literacies in the Classroom through Collaborative Problem Solving Supported by Digital Pens and Interactive Whiteboards. Computers \& Education. 63 : 368-379.

Amoros, M. J. H. \& Solano, M. E. 2017. Working with Emotions in the Classroom: Future Teachers' Attitude and Education. Procedia - Sosial and Behavioral Science. 237 : 511-519.

Caresia, F. 2017. Sunny Island: An Interactive Learning Evironment to Promote Systems Thinking Education for Primary School Students. Procedia - Social and Bhavioral Science. 237 : 980-985.

Carmona, R. M \& Chacon P. 2017. Arts Education and Media Literacy in the Primary Education Teaching Degree of the University of Granada. Procedia - Sosial and Behavioral Science. 237 : 1166-1172.

Ceretti, F. C. 2015. MAIA (Movie Analysis in Action): A New Teaching Method in Media Literacy Education. Procedia - Sosial and Behavioral Science. 174 : 4053-4057.

Chen, W. Shah, U \& Brechtelsbauer, C. 2016. The Discovery Laboratory- A StudentCentered Experimential Learning Practical. Procedia - Sosial and Behavioral Science. 17 : 44-53.

Clarke, J. 2010. Student Centered Teaching Methods in a Chinese Setting. Education Today. 30 (1) : 15-19.

Darmawan, D. 2012. Inovasi Pendidikan. Bandung: PT Remaja Rosdakarya.

Diergarten, A. K. Mockel, T. Nieding, G. \& Ohler, P. 2017. The Impact of Media Literacy on Childre's Learning from Films and Hypermedia. Journal of Applied Developmental Psychology. 48 : 33-41.

Dragons, V \& Mih, V. 2015. Scientific Literacy inSchool. Procedia - Social and Bhavioral Science. 209 : 167-172. 
Fajriah U. N. \& Churiyah, M. 2016. Utilizing Instructional Media for Teaching Infrastructure Administration. Journal of Education and Practice, (Online), 7 (6): 100-111, (www.iiste.org), diakses 1 maret 2017.

Friedman, A. 2016. Three-Years-Old Photographers: Educational and Parental Mediation as a Basic for Visual Literacy via Digital Photography in Early Childhood. Journal of Media Literacy Education, (Online), 9 (1): 15-31, (http://sdwc.net/ijeetdm), diakses 2 Desember 2016.

Hosnan, M. 2014. Pendekatan Saintifik dan Kontekstual dalam Pembelajaran Pembelajaran Abad 21. Bogor: Ghalia Indonesia.

Hsiao, H. S \& Chen, Jvun-Chen. 2016. Using a gesture Interactive Game-Based Learning Approach to Improve Preschool Children's Learning Performance and Motor Skills. Computers \& Education. 95 : 151-162.

Jaradat, M. 2013. Students' Motivation and Instructors' Technology Use in Higher Education: A Case Study in the Gulf Region. Journal of Education and Practice, (Online), 4 (19): 127-138, (www.iiste.org), diakses 1 maret 2017.

Karadeniz, A \& Can, R. 2015. A Research on Book Reading Habits and Media Literacy of Students at the Faculty of Education. Procedia - Sosial and Behavioral Science. 174 : 4058-4067.

Karaduman, S. 2013. An Assessment on Media Literacy Education in Turkey and the Problems Ecperienced in Practice. Procedia - Sosial and Behavioral Science. $106: 371-379$.

Karaduman, S. 2015. The Role of Critical Media Literacy in Futher Developmen of Conscioisness of Citizenship. Procedia - Sosial and Behavioral Science. 174 : 3039-3043.

Kemendikbud. 2016. Peringkat Pendidikan Dunia (World Education Rangking). (Online), (http://www.kemendikbud.go.id), diakses 5 Mei 2017.

Kusumajaya, F. A. Kusumajanto, D. D. \& Sarbini. 2016. Efektivitas Pemanfaatan Media Visual Untuk Meningkatkan Hasil Belajar Mata Pelajaran Korespondensi Pada Siswa Kelas X Administrasi Perkantoran di SMK Muhammadiyah 5 Kepanjen. Jurnal Pendidikan Bisnis dan Manajemen, (Online), 2 (1): 94-101, (www.journal.um.ac.id), diakses 6 Desember 2016.

Lee, L. Chen, D. T. Ling, T. B. 2015. Understanding New Media Literacy: The Development of a Measuring Instrument. Computers \& Education. 85 : 84-93.

Mahajan, G. 2012. Multimedia in Teacher Education: Perceptions \& Uses. Journal of Education and Practice. (Online), 3(1): 16-22, (www.iiste.org), diakses 2 Maret 2017. 
Nookhoong, J. \& Wannapiroon, P. 2015. Development of Collaborative Learning Using Case-Based Learning via Cloud Technology and Sosial Media for Enhancing Problem-Solving Skills and ICT Literacy within Undergraduate Students. Procedia - Social and Behavioral Sciences. 174 : 2096-2101.

Norman, E. \& Furnes, B. 2016. The Relationship Between Metacognitive Experience and Learning: Is There a Difference Between Digital and Non-Digital Study Media?. Computers in Human Behavior. 54 : 301-304.

Permendikbud 64 Tahun 2013 tentang Standar Isi. Badan Penelitian dan Pengembangan Kementrian Pendidikan dan Kebudayaan. (Online), (http://www.litbang.kemendikbud.go.id), diakses 9 November 2016.

Olabiyi, O. S, Aiyelabowo, O. P \& Keshinro, 0. T. 2013. Relevance of Computer Assisted Instruction (CAI) for Effective Skill Development among Technology Education Students in Nigeria. Journal of Education and Practice. (Online), 4(21): 80-89, (www.iiste.org), diakses 2 Maret 2017.

Paola, F. D.,Pedone, P \& Pizzurro, M. R. 2013. Digital and Interactive Learning and Teaching Methods in Descriptive Geometry. Procedia - Social and Bhavioral Science. 106: 873-885.

Putri, D. I. Pratikto, H. \& Wardana L. W. 2016. Pengembangan Media Autoplay untuk Meningkatkan Hasil Belajar Siswa pada Mata Pelajaran Prinsip-Prinsip Bisnis. Jurnal Pendidikan Bisnis dan Manajemen (Online), 2 (2): 133-138, (www.journal.um.ac.id), diakses 6 Desember 2016.

Rahmania, F. D. Sutrisno \& Suputra, I Nyoman. 2016. Pengembangan Media Movie Maker Pada Mata Pelajaran Kearsipan Kelas X Administrasi Perkantoran. Jurnal Pendidikan Bisnis dan Manajemen (Online), 2 (1): 41-49, (www.journal.um.ac.id), diakses 6 Desember 2016.

Roman, I. 2015. Development of Agronomic Education by Student-Centered Learning. Procedia - Sosial and Bhavioral Science. 180 : 441-447.

Sanjaya, W. 2008. Perencanaan dan Desain Sistem Pembelajaran. Jakarta: Kencana Prenada Media Group.

Schroder, H. Fisher, M. E. Lin, Y. Lo, S. L. Danovitch, J. H. \& Moser, J. S. 2017. Neural Evidence For Enhanced Attention to Mistake Among School-Aged Children with Growth Mindset. Developmental Cognitive Neuroscience. 24 (1) : 42-50.

Setyosari, P. 2013. Metode Penelitian Pendidikan dan Pengembangan. Jakarta: Prenadamedia Group. 
Sharma, A. \& Gandhar, K. 2011. Role of ICT in the Process of Teaching an Learning. Journal of Education and Practice (Online), 2(5): 1-5, (www.iiste.org), diakses 2 Maret 2017.

Siddiq, F., Gochyyev, P \& Wilson, M. 2016. Learning in Digital Networks - ICT Literacy: A Novel Assessment of Students' 21st Century Skills. Computers \& Education. 109 (5) : 11-37.

Sisman, B \& Yurttas, O. U. 2015. An Empirical Study on Media Literacy from The Viewpoint of Media. Procedia - Sosial and Behavioral Science. 174 : 798-804.

Taheri,dkk. 2016. A Study of Teaching Problem Solving and Programming to Children by Introducing a New Programming Language. The International Journal of E-Learning and Education Technologies in the Digital Media(Online), 2 (1): 31-36, (http://sdwc.net/ijeetdm), diakses 22 November 2016.

Tyabaev, A. E. Sedelnikova, S. F \& Voytivich, A. V. 2015. Student-Centered Learning: The Eksperience of Teaching International Students in Russian Universities. Procedia - Sosial and Behavioral Science. 215 : 84-89.

Wang, D. 2011. The Dilemma of Time: Student-Centered Teaching in The Rural Classroom in China. Teaching and Teacher Education. 27 (1) : 157-164.

Waseem, K. Kazmi, H. A. \& Qureshi, O. H. 2016. Innovation in Education - Inclusion of 3D-Printing Technology in Modern Education System of Pakistan: Case from Pakistani Educational Institutes.Journal of Education and Practice. . (Online), 7 (36): 1-6, (www.iiste.org), diakses 2 Maret 2017

Yada, A. \& Savolainen H. 2016. Japannese In-Service Teachers' Attitudes Toward Inclusive Education and Self-Efficacy For Inclusive Practice. Teaching and Teacher Education. 64 (6): 222-229

Yang, H. H. \& Yin, S. K. 2016. A Study of Elementary School Students' Reasoning using Digital Origami Simulation Tool. The International Journal of E-Learning and Education Technologies in the Digital Media (Online), 2 (1): 1-8, (http://sdiwc.net/ijeetdm), diakses 22 November 2016 